Perspective

\title{
Indigenous Natural and First Law in Planetary Health ${ }^{\dagger}$
}

\author{
Nicole Redvers ${ }^{1,2, *} \mathbb{0}$, Anne Poelina ${ }^{3}$, Clinton Schultz ${ }^{4}$, Daniel M. Kobei ${ }^{5}$, Cicilia Githaiga ${ }^{6}$, \\ Marlikka Perdrisat ${ }^{7}$, Donald Prince ${ }^{8}$ and Be'sha Blondin ${ }^{2}$ \\ 1 School of Medicine \& Health Sciences, University of North Dakota, 1301 N Columbia Rd Stop, \\ Grand Forks, ND 58202, USA \\ 2 Arctic Indigenous Wellness Foundation, Box 603, Yellowknife, NT X1A 2N5, Canada; \\ bblondin@northwestel.net \\ 3 Nulungu Research Institute, University of Notre Dame Australia, PO. Box 2747, Broome, WA 6725, Australia; \\ anne@majala.com.au \\ 4 Faculty of Medicine \& Health Sciences, Bond University, 14 University Drive, Robina, QLD 4226, Australia; \\ clinton@marumaliconsult.com \\ 5 Ogiek People's Development Program (OPDP), Egerton PO Box 424-20115, Kenya; dkobei@ogiekpeoples.org \\ 6 Wangari Githaiga \& Co Advocates, Muthaiga Suites, 1st Floor, Suite 12, Vuli Lane, Off exit 4, \\ Muthaiga Interchange, Thika Superhighway, Nairobi PO Box 58945-00200, Kenya; \\ githaigaadvocate@gmail.com \\ 7 Sydney Law School, The University of Sydney, New Law Building, Eastern Avenue, Camperdown Campus, \\ Sydney, NSW 2006, Australia; mper7383@uni.sydney.edu.au \\ 8 Nakazdli Whut'en, PO. Box 1785, Fort St. James, BC V0J 1P0, Canada; donaldprince20@gmail.com \\ * Correspondence: nicole.redvers@und.edu; Tel.: +1-701-777-6096; Fax: +1-701-777-3277 \\ + We formally acknowledge Mother Earth as our senior author, with her own presence and voice.
}

Received: 29 September 2020; Accepted: 26 October 2020; Published: 28 October 2020

check for updates

\begin{abstract}
Indigenous Peoples associate their own laws with the laws of the natural world, which are formally known as or translated as Natural or First Law. These laws come from the Creator and the Land through our ancestral stories and therefore, they are sacred. All aspects of life and existence depend on living and following these natural First Laws. Since colonization, Indigenous Peoples' Natural Laws have been forcibly replaced by modern-day laws that do not take into account the sacred relationship between the Earth and all of her inhabitants. The force of societies who live outside of Natural Law has ensured the modern-day consequences of not living in balance with nature. Pandemics and global environmental change, including climate change, are all consequences of not following the Natural Laws that are encapsulated by the interconnected nature of the universe. Here we discuss Natural Law from an Indigenous paradigm and worldview which carries implications for planetary health and wider environmental movements around the globe.
\end{abstract}

Keywords: Indigenous health; planetary health; environmental health; justice; health equity; Natural Law; First Law

\section{Introduction}

"The culture's vitality is literally dependent on individuals, in community with the natural world. Indigenous cultures are an extension of the story of the natural community of a place and evolve according to ecological dynamics and natural relationships". [1] (p. 20)

Indigenous Peoples currently host and live in areas that hold eighty percent of the world's biodiversity and yet they inhabit only twenty two percent of the earth's surface [2]. They manage 
or have tenure rights over at least $\sim 38$ million $\mathrm{km}^{2}$ in 87 countries or politically distinct areas on all inhabited continents [3]. Indigenous Peoples have developed knowledge over thousands of years about their natural rootedness, and they have actively maintained their vast ecosystems through reciprocal relationships. Indigenous traditional knowledge has in turn served, often without explicit consent or acknowledgment, entire nations for generations by providing ecosystem and provisioning knowledge and services such as food, medicine, and mineral resources. The extraction of knowledge and resources through forceful colonizing agendas has created a disconnect between the original meaning of this knowledge and how this knowledge is used in current landscapes. This creates a dangerous and precipitous situation where the realities of our existence have been stressed to the breaking point, as evidenced by current global environmental change (e.g., climate change, polluting of watersheds, pandemics).

From an Indigenous land-based worldview, where this original knowledge is rooted, all is considered alive, of living energy, and of spiritual value rather than materialistic or financial value. This is in stark contrast to capitalist systems that largely function on the commodification of nature and are ecocidal [4]. Indigenous Peoples clearly understand that any detrimental interference with the natural world's rhythms and "being" impacts directly on our well-being. For example, for the Dene Peoples of Dakelh, British Columbia, Canada, everything is connected. The land, animals, plants, people, and universe are held together by a power (Yudughi) that connects everything. When this important connection is broken or displaced, then other systems get thrown out of line. This is one of the reasons why when we take something (e.g., harvesting 'medicines' from the land), we then need to replace it with something (i.e., a spiritual offering to the land). This action demonstrates a deep and intentional reciprocal relationship founded in the knowledge of the power $(Y u)$ all around $(D u)$ that holds things together $(G h i)$. This interconnectedness is deeply profound and seeds our understanding of the relationships we have with our environment.

Professor Michael McDaniels, the head of Indigenous Knowledge and Pro Vice Chancellor at the University of Technology, Sydney, provided an eloquent narration of this concept in that "interconnectedness of country, of people, of winds, of water, of constellations, of people past and people future, of the web of life ... that to touch one element of the web of life is to affect all" [5]. Caring for Land or Country so Country or Land can care for us is how many Indigenous Peoples will explain this interconnected relationship. Land or Country itself can be explained as the way in which Indigenous Peoples refer to a place that gives and receives life, for and from its peoples [6]. Therefore, Country and Land are explicitly alive and are a life support for all else [7].

With this, we as Indigenous community members, land defenders, water protectors, researchers, providers, and servants to Mother Earth and our people, collectively embrace the need to re-establish dynamic balance to our shared home. We see this done in a way that fits with the natural rhythms of laws that have been storied in our various cultures around the globe for countless generations. We therefore assert that it is vitally important to understand the nested but interconnected levels of existence on which our health depends (see Figure 1). These interconnected levels will form the basis and structure of this discussion.

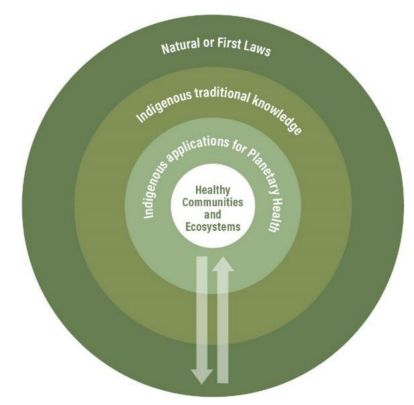

Figure 1. Nested levels of knowledge and applications that surround healthy communities and ecosystems (adapted from [8]). 
Although Mother Earth is a living system that can transform and heal, she will be lonely without the vibrations of her human family. Therefore, in this combined effort, deeply rooted in our collective knowledge traditions and representing the four directions, we seek to humbly offer a way forward through a cultural bridging discourse. Indigenous community conceptions of Natural Law or First Law (both terms are used interchangeably throughout), are an underappreciated window into how Indigenous Peoples around the globe have been able to act as ongoing stewards of their environment in service to Mother Earth, and therefore, as curators of our current existence. Although the term "Natural Law" (ius naturale, lex naturalis) has been used in various Euro-Western traditions and contexts, the meaning and application of the concept in these circles are vastly different to those within Indigenous communities. This brief introduction to the Indigenous representation of the topic is meant to be stimulatory, reflective, and actionable, introducing realities and concepts that are missing from current planetary health, environmental, and climate change movements and scholarship, and which are integral to the continuation of existence.

We would also like to formally acknowledge our senior author, Mother Earth, as she is often not given a voice or formal presence despite the millions of articles, research, and work done on, to, and for her. Instead, we are with, by, and as her, as she lives within each of us as the root of our existence.

\section{Natural Law or First Law}

First Law, Law of the Land Not Law of Man

"Jayida Booroo, yimartuwarra marnins. Welcome to our Country. We, Anne Poelina and Marlikka Perdrisat, are women who belong to the Martuwarra Fitzroy River, in the Kimberley region of Western Australia, Australia."

We come as Indigenous insiders, mother, and daughter to share our values, ethics, and thoughts regarding Natural Law, First Law, and the Law of the Land in contrast to the colonially imposed Law of Man. First Law is the guiding principle of First Peoples and it has been generated over eons to govern the diverse range of bioregions within the land mass currently known as Australia. It is the body of laws responsible for maintaining respectful and reciprocal relations between and within First Nations and between the human and non-human family.

As traditional custodians of the Martuwarra (Fitzroy River), we derive our identity and existence from this globally significant River. Martuwarra would be best described as an "ancestral being", a legal subject that possesses legal rights [9]. This is different from the legal subject of "personhood", for which there is increasing ambivalence among some traditional landowners due to important questions on the actual legal usefulness of this term [10] and whether or not the term dilutes the duty of care needed to protect our ancestor. As the River is already an entity, it should not have to depend on the specific actions of settler law to achieve this status [10].

Our epistemological and ontological lived experience has been informed by tens of thousands of years of memories that are stored in our stories. The meaning of these stories informs our contemporary dreaming. When Aboriginal people are born, we are given a totem. In our Nyikina culture a totem is known as Jadiny. In framing the concept of totemism, Deborah Bird Rose describes totem as "a common property institution for long-term ecological management" [11]. The totem is your kin, and Aboriginal people are given a totem to teach them that they have a kinship relationship with non-human beings.

This relationship creates empathy and a lifelong relationship through practicing the ethics of care. This teaches traditional owners about the ecological balance between humans and nature. Traditional owner groups have sustainably managed discrete estates along the River for countless generations. Shared totems connect people of the past with future generations. Each generation is responsible for respecting and protecting the River from harmful risks.

First Law embodies the concept that is known regionally as Liyan-the feeling of a deep personal relationship with all living and non-living things [9]. This relationship is a logical, personal understanding of how to do the right thing. Our values, ethics and culture support sustaining the environment and 
balance of life as the primary intent of law. Liyan is the spirit within us that connects us to the universal spirit of life. First Law is about creating positive energy and being true to ourselves, so that our spirits are at peace.

We are from the oldest continuous society in the world, and for us, as with other First Nations Peoples, it is all about our stories. Our ancient wisdom is maintained and shared through countless generations of storytelling. This ancient cultural wisdom that is transmitted through our stories is greatly needed during this time of global upheaval (i.e., climate change, emerging pandemics, escalating inequities).

First Law itself in Australia differs markedly from its colonial counterpart [9]. First Law principles are not expressed in terms of external rules, policies, and procedures by government to influence individual and societal behavior through fear. First Law is applied through multilayered stories that impart values and ethics; thus they represent a comprehensive ethical framework that defines the codes of conduct necessary for maintaining a peaceful, thriving, and co-operative society grounded in love and reciprocity.

The Warloongarriy songline is the First Law governing the Martuwarra. First Nations along the River share a common songline that sets out community and individual rights, relationships, and responsibilities. Ceremonial songline law is passed to each emerging generation by raising their spirit through singing and dancing. Martuwarra First Law includes Warloongarriy Law (River Law) and Wunan Law (regional governance law) [9]. For example, Wunan Law is a cooperative model based on principles that respect the sovereignty of the Indigenous nations, but ensure the well-being of River, Sea, Ranges (Hill), and Desert Country by viewing it holistically and treating it as an integrated, connected whole. Prior to colonization, the Wunan was the Indigenous regional governance system for an extensive trade exchange based on co-existence and co-management principles across vast estates of land spanning from the Kimberley to the Northern Territory.

Our relationship with the River requires that we act with empathy as it is our fiduciary duty to protect land and living waters, and our non-human family. Invasive or unjust development would constitute a breach of our customary First Law as it impacts on our responsibility to maintain living human and ecological systems.

Colonial laws were imposed over First Law with the intent of extracting private wealth at the expense of the diminished quality of life and well-being of those already living within this Country. First Law recognizes the River as a living entity and therefore it has a right to live and flow. The River generates a positive living spirit that creates and sustains all life in the River Country. Traditional owners of the Martuwarra are seriously challenged by the notion of doing anything that is going to have a negative impact on the River. It defies logic and disheartens individuals and whole communities of people who have a deep relationship with the spirit of our place, our ancestral estate. Due to this, it is important to have legal instruments in place to ensure that First Peoples views and rights are respected. An example of a more constructive approach to recognizing our rights under the common law of Australia is to be found in the recent decision of the Federal Court of Australia regarding Fortescue Metals Group (FMG) vs. Warrie on behalf of the Yinjibarndi People [12]. The determination identified

The very foundation of traditional Aboriginal law and customs is in the spiritual and the intermingling of the spiritual with the physical, with people and with land ... [Furthermore] ... the distinctions between spiritual belief and real property rights, or personal property rights, are not to be imported into an assessment of the existence and content of Aboriginal customary law. To do so would be to destroy the fabric of that customary law [12].

This type of legal judgement is an expression of legal pluralism that demonstrates that First Law can coexist with imposed, anthropocentric laws. The decision legitimizes First Law stories and considers them necessary to uphold the spiritual balance and harmony of life between people and nature.

First Law values honesty, empathy, love, and justice to promote a cooperative spirit, interdependence, and coexistence. In a time of world dis-ease over the COVID-19 pandemic, 
rising tensions between political and economic superpowers, and increasing international mistrust of governments, we find meaning in First Law creation stories. Our stories give us the authority to question the legal and moral justification for imposing one law over another. Colonization continues because the intent of colonial-derived laws is to exclusively benefit man and human communities over the needs of the land, water, and all the living spirits that constitute our unique biosphere. The outcomes of many of the new laws diminish Indigenous guardianship, responsibility, and authority.

\section{Indigenous Traditional Knowledge}

\section{"Working in alliance with nature and her natural laws is the key to ensuring our survival". [13]}

Failure to protect planetary boundaries [14] through the rooted cross-cultural knowledge of Natural or First Law will challenge the ability to protect the planet. Indigenous traditional knowledge (TK) is directly nested within the understanding of Natural or First Law. TK can be defined as "all that is known about the world around us and how to apply that knowledge in relation to those beings that share the world" [15]. TK systems are more species and environmentally inclusive which roots the current broad and increasingly heightened concern about the rate of loss of our ecosystems and the impacts of this on the life and balance of Mother Earth [8]. Indigenous TK has resiliently spanned millennia; however, it is only recently that we have seen a growing recognition of the importance of TK as a foundation for global climate and health solutions [16].

The Intergovernmental Science-Policy Platform on Biodiversity and Ecosystem Services (IPBES) has suggested that there is a great risk that Indigenous Peoples will lose their traditional knowledge [16]. This is due to the continued loss of Indigenous Peoples' land bases and the consequent loss of biodiversity, which directly impacts communities that rely on nature for their traditional medicine, conservation, and cultural rights, among other uses [17]. Two specific international instruments, the Convention on Biological Diversity (CBD) [18] and the Nagoya Protocol (NP) [19], have given Indigenous Peoples the impetus to further conserve the environment in which they live, to protect their traditional knowledge, and to ensure that their knowledge is preserved and passed on from generation to generation. These tools were created with the intent that benefits generated from outside access and utilization of biologic and genetic resources, in addition to TK (i.e., knowledge, innovations, and practices), would be shared equitably. However, large barriers remain in place globally, such as the lack of uptake and actioning of the UN Declaration on the Rights of Indigenous Peoples, which means that the ongoing impacts of colonialism continue to leave many Indigenous communities vulnerable, unrecognized, and without autonomy. However, Indigenous Peoples have diverse notions of resiliency that are grounded in culturally distinct concepts that bridge person, community, and the environment [20], thus, we have seen much strength grown from these hardships, resulting in actionable agendas to ensure the continued preservation of our lands and communities.

Several other specific community-based instruments have been used by Indigenous Peoples to define their values, who they are, and what they expect from external stakeholders when they come onto their lands including such tools defined as Bio-cultural Community Protocols (BCPs). A specific example of this, is the Ogiek Peoples of Kenya Bio-cultural Protocol [21] and the Endorois Peoples of Kenya Bio-cultural Protocol [22]. These instruments are important as they define the culture and heritage of the Ogiek and Endorois Peoples while helping external stakeholders understand how to interact with these groups to avoid undue conflict in the region. Even more critical is the fact that these instruments outline the culture of the community, their relationship with the land in which they live, and the natural environment, including the plants and animals relevant to the community [21,22]. The Endorois and Ogiek Peoples' BCP are also provided as negotiating tools that allow them to engage with government and other stakeholders about matters that affect them [21,22]. The Ogiek Peoples' $\mathrm{BCP}$ was also developed to enable them to have a tool to engage with the government and other stakeholders when they were faced with eviction from their ancestral homeland, the Mau Forest, by the Government of Kenya [21]. 
The Mau Forest's bio-capital value is important not only to the Ogiek Peoples of Mau, but is also key for the economy of Kenya and the region. This value is especially important considering that it is one of five water towers in the country of Kenya [23]. The Mau Forest covers approximately 400,000 hectares, a large percentage of which has been destroyed by farmers who have encroached on the forest [23], a factor that has led to the ongoing displacement of the Ogiek Peoples. The Ogiek Peoples believe that they were given the Mau Forest by God, and hence they attach a high spiritual value to their ancestral land. This spiritual attachment to the Mau Forest is the same as the one experienced by the Endorois Peoples. The cultural value of the natural elements to the Ogiek and Endorois Peoples, in addition to their deep attachment to the land and other aspects of their Indigenous life, was examined by the African Commission in the case of the Endorois Peoples [24,25], and by the African Court in the case of the Ogiek Peoples $[25,26]$. Both of these cases were instituted against the Government of Kenya (the Ogiek case in 2009, and the Endorois case in 2003). In both cases, the Government of Kenya was found to have violated the communities' rights to culture, to religion, and to their rights to land and natural resources [25]. The Ogiek community has pushed the Kenyan government for customary ownership of the Mau Forest, on which their livelihoods depend, but instead they have been evicted from their ancestral lands. As a result of a long-winded litigation that lasted seventeen years in Kenya, the Ogiek Peoples subsequently filed an application with the African Commission, which took up the case and ruled in their favor on the 26th of May, 2017; however, three years later the judgment has yet to be implemented [23]. Due to the direct relationship and entwined nature of the successful inter-generational transfer of traditional ecological knowledge and being in relationship with one's own land or country [27], ensuring that transpolitical tools are in place to protect land rights for Indigenous Peoples globally is the foundation for sustaining TK's important place in this world. Our very survival as a human species will depend on it as current trajectories for achieving sustainability goals will not meet our needs, the needs of our communities or that of the planet [28].

The Ogiek and Endorois Indigenous Peoples' own traditional knowledge has allowed them to thrive as a people through their abiding understanding of their own Natural Laws, which are partly documented in their bio-cultural community protocols. These Natural Laws are implemented through oral TK protocols that include rules on how to interact with nature, such as imposing restrictions that ban communities from cutting trees, or instead lead to the prioritization of the use of only certain parts of trees and roots in a bid to utilize their resources sustainably. They are barred from killing animals, instead, they are bound to protect animals. The people were also not allowed to interfere with water sources and sacred sites except for a few sacred Elders or other groups allowed by custom, among other examples [21,22]. The Ogiek Peoples refer to the Mau ecosystem as their home; it is all they have, and at the same time it is a place where they have direct links with their ancestors. They perform their cultural practices including spiritual ceremonies here [21,23], and the community respectfully and with great care utilizes Mau as their "supermarket", where they get all they need in life for their well-being. As noted, this is not only limited to forest products themselves, but also the important connection to the spirits of their ancestors [21,23]. They have many lessons to teach the world on how to maintain healthy ecosystems and take care of Mother Earth [3,29].

It has been determined that $24 \%$ of the global carbon stored above ground in the world's tropical forests, or 54,546 million metric tonnes of carbon, are currently being managed by Indigenous Peoples [29]. This ability to live in harmony with nature has been attributed to Indigenous Peoples' historical stewardship, traditional knowledge, and cultural innovations that are directly rooted in Natural Law. This way of living and being has the potential to be respectfully leveraged through Indigenous community-led and defined leadership while providing valuable lessons on how to respectfully and resiliently live sustainably with nature $[3,29]$. With the needed tools for the adaptation and mitigation from the impacts of climate change and other global environmental changes [3,29], respectful acknowledgment of TK through the recognition of Indigenous land and water rights are however integral for realizing a platform for equitable discourse. 


\section{Indigenous Applications for Planetary Health}

The term, "planetary boundaries" has recently been introduced and defined as the safe "planetary playing field", or the "safe operating space for humanity" to stay within if we want to be sure to avoid major human-induced environmental change on a global scale [13]. This more modern idea and notion of planetary boundaries has been considered old knowledge by Indigenous Peoples from time immemorial. For example, for the Dene Peoples of Northern Canada,

Elders were in charge of monitoring hunting and fishing in their communities. They [the Elders] were experts in ensuring the sustainability of their food sources. For example, if a certain area was used for hunting or a certain lake for fishing, it would only be allowed for up to ten years in some cases; and then community members were required to halt all harvesting for five years or so to let the populations re-bound while moving to another area for harvesting in the meantime. [30] (p. 113)

The understanding of planetary boundaries as being fixed within Natural or First Law, is reflected globally in the sustainability practices that have ensured Indigenous Peoples' long survival in some of the harshest and most plentiful environments on the planet. It must be acknowledged that "planetary health" as a field is primarily a Western construct as Indigenous TK systems have no clear separation between the health of the planet and the health of self or that of the community and ecosystem at large [19]. This means that applications for planetary health are directly rooted in community values based on protocols for living in harmony with all.

For the Northern Dene Peoples, Yamoria was a powerful medicine man and a prophet. "He was a true spirit man who taught the Dene how to live a sacred life" [31]. Yamoria taught the people through a set of "environmental laws" (or natural laws) that the Dene were not only to honor and follow but to "prepare the children for a good life by teaching them in this way. It is our responsibility to do this" [31]. The laws are premised on such important teachings as finding a balance in how we give and take from Mother Earth, the need for treating Mother Earth with respect, and staying in harmony with all the Creator's creations. For the Cree Peoples of Canada, Wahkohtowin is a word that means "everything is related." It is one of the basic principles of Cree Natural Law passed down through language, song, prayer, and storytelling [32]. The Cree Elders explain that individuals, communities, and societies are healthier by following the teachings of Wahkohtowin [32].

The return to Indigenous values in our current societal landscapes are an underappreciated and crucially needed element of practice. Elder David Courchene (Nii Gaani Aki Innini) of the Anishinaabe Nation states that:

The reason we have climate change is because we have broken Natural Law. What is Natural Law and how can we find our balance again? ... The spirit in each of our beings carries moral and ethical principles of what should be the basis of our human conduct. We understand these moral principles as natural laws. Natural laws are innate to all living beings. They are the invisible laws that govern all life. All living beings, including Mother Earth herself, are governed by natural laws —whether they know it or not. [12]

Natural Law is grounded in a clear set of cultural protocols (or we could say "rules" nested in ceremonial action). We must follow these protocols in our application of daily life as these protocols clearly define a sustainable relationship with Mother Earth and therefore with our communities. Many of these protocols are rooted in relationship, which means they are rooted in love. Love and gratitude are embodied in Natural Law as Mother Earth gives and receives these. This reciprocal and respectful relationship takes great courage and sacrifice as the "Windigo" of greed and gluttony is very persuasive in a world of consumtogenic pressures and expectations. Many Anishinaabeg Peoples of Turtle Island refer to the "Seven Grandfather Teachings" as traditional knowledge that collectively represents what is needed for community survival [33]. The Seven Grandfather Teachings are an example of how to live a good life through the concepts of Respect (Minwaadendamowin), Love (Zaagidiwin), 
Truth (Debwewin), Bravery (Aakodewewin), Wisdom (Nibwaakawin), Generosity (Miigwe'aadiziwin), and Humility (Dibaadendiziwin). Indigenous knowledge traditions in many contemporary communities located in Turtle Island (North America), are also still founded on and embody what the Haudenosaunee Peoples call, for example, the "Seventh Generation Principle" [34]. The Seventh Generation Principle generally states that any decision taken today should consider the impact of those decisions on the next seven generations that come after us [34].

Ultimately, as Aboriginal Australian Christine F. Black states in her book The Land Is the Source of the Law (2010), "the Djang (primordial energy) is out of balance, and the rebalancing of that Djang is up to the individual through their lawful behavior; a behavior which patterns them back to the land" [35]. Therefore, Indigenous applications for planetary health are completely rooted in the values that ground our societies to the Land, and it is through these values that we uphold Natural or First Law that governs the planet and keeps us within sustainable planetary boundaries.

\section{Healthy Communities and Ecosystems}

\section{Gamilaraay Notions of Lore, Planetary Health and Wellness of $U s$}

Gayrr ngaya Clinton, ngaya Gamilaraay (My name is Clinton Schultz, and I am Gamilaraay). I offer the below as an introduction to the Indigenous country and mindset from which I write.

The Gamilaraay/Gomeroi Peoples are the peoples of the land more recently recognized as North West New South Wales in Australia. Gamilaraay country is marked by important river systems that flow south into the greater Murray Darling Basin, the major freshwater resource of much of the "agricultural" lands of Eastern and Southern Australia.

Lore, or what is termed in the Gamilaraay language, dhiriya gamil (i.e., First law or Original Law), is the foundation of who we are as Gamilaraay (Aboriginal) Peoples, the original custodians of Gamilaraay country. Dhiriya gamil was given to us by the creator, Buwadjarr, who is of "before the beginning" $[7,36,37]$. Dhiriya gamil is what gives rise to our culture, our identity, and our spiritual connection with place and allows the Gomeroi to know their roles and responsibilities to Gamilaraay country. The old people explained lore to me as the "essence of what 'is'" and culture as being "how we enact that 'what is." As Gamilaraay, dhiriya gamil is therefore the essence of what it is to be Gamilaraay in connection to a Gamilaraay existence [7]. Dhiriya gamil always guides me in my intrinsic, reciprocal roles and responsibilities while allowing me to fulfill my part in the continuation of a healthy existence for all. Dhiriya gamil or First Law comes from "before the dreaming" (i.e., before human existence in the physical form). In Gamilaraay, we refer to this before the dreaming period as burruguu, which simply means "the dream time" but it also equates to the "time of original creation". This before the dreaming period of Burruguu is an ongoing and interconnected part of burruguu-ngayi-li, or what people commonly describe in English as simply "dreaming" [37], or what we also may refer to as "my dreaming" (i.e., we are intimately connected through our dream time to our innate existence and the laws on which this depends). Burruguu-ngayi-li, is a continuation of creation through the guidance of dhiriya gamil for the maintenance of all that we are connected to as Gamilaraay.

Here, I formally story notions of lore, planetary health, and the wellness of Gamilaraay Peoples fortunate enough to share this planet and to be caretakers of Gamilaraay country. “Oneness' through reciprocal roles and responsibilities, in addition to shared place across time are the foundations of dhiriya gamil (First Law). This oneness is a concept understood in two ways. Firstly, bil maal, literally meaning "all one", is a concept that speaks to the ways in which we understand the constant interplay between everything we say, think, and do, in addition to all we are connected to $[7,36]$. Secondly, gawuban gunigal speaks to the inherent relationships we share and connections we have with all of nature, the creatures, winds, air, waters, and land [37]. The complexities of our traditional knowledge systems embodied through our language is powerfully demonstrated here.

Gamilaraay clearly understand that detrimental interference with anything within the natural world impacts back on our individual and community well-being. When our well-being is impacted 
in a negative way, this in turn plays on our abilities to maintain processes of "caring for Country". The opportunity to engage in caring for Country (or caring for Land) has been shown to directly and positively influence the well-being of Aboriginal Peoples [38,39]. On the other hand, living in environments that have become "uncared for" due to the processes of colonization can be directly linked to poorer health conditions, not only for Aboriginal Peoples but for settler populations as well.

If we consider the recent bush fire events of the summer of 2019-2020 in Australia, it is clear that there has been little opportunity to care for Country through the cleansing burn-off practices that are rooted in Indigenous fire-keeping practices, and this has enabled out-of-control fires to rage. This has significantly and negatively impacted the lives of all humans, animals, and ecosystems in the area. Thirty-three people unfortunately lost their lives with possibly many more deaths linked to the smoke related to the fires [40]. Many people today are still without shelter or livelihoods and there was a notable and unprecedented loss of wildlife [40]. Nearly three billion animals were killed or displaced by the 2019-2020 bushfires alone [41]. The Mother (Earth) cleansed herself through these fires as she has done time and time again across all of time. She will heal and continue on well after we have all departed, that is a given, but she will be lonely without us.

Returning to our lore is a way to ensure that we have the opportunity to continue to co-exist with the Mother and all that she holds. Having the opportunity to teach those from other interconnected communities for whom these concepts and knowledges may not be so naturally understood or respected will provide a platform for us to move forward in a united and collective way toward a better future for all. Bil maal gii dhuwi, "all one heart and spirit".

\section{Conclusions}

"Rocks and trees are sentient beings, sacred in their own right and entitled to great respect from human beings". [42]

Our collective position is summarized here with a recapitulation of the findings from Toledo that the world's biodiversity will only be preserved by directly and intentionally preserving the diversity of cultures and vice versa [43]. This has direct implications for human health due to the critical connection between biodiversity loss and the increased risk of pandemics such as COVID-19 [44]. In some respects, the lands of Indigenous Peoples are the only ones still left intact and thus, they continually attract interest from governments, the private sector, and other stakeholders, not only for resource extraction but for knowledge and innovation extraction as well. International tools, such as the UN Declaration on the Rights of Indigenous People [45], require "free, prior, and informed consent" [46] to be prioritized for the sharing of appropriate planetary co-benefits. Further creative and peaceful exploration that combines Indigenous traditional knowledge with scientific and technological developments to inform urgently needed solutions to global problems [29] provides an undeniable opportunity to re-establish balance to Mother Earth [47]. This can be juxtaposed with the unfortunate and continued reality of land grabbing, eviction, incarceration, and the death of Indigenous Peoples on the front lines protecting our Mother Earth [29]. Without intentional and actioned global solidarity with our Indigenous brothers and sisters' efforts to steward and protect their Land and Country from appropriation, extraction and exploitation, efforts and progress toward the maintenance of planetary health and planetary boundaries will be significantly hampered.

Therefore, we collectively affirm the importance of understanding the nested but interconnected levels of existence on which our health depends. In our view, the interconnectedness between Indigenous Natural or First Law and its implications for planetary health through the lens of Indigenous traditional knowledge systems are integral to the realization of healthy communities and ecosystems. Ultimately, individual, community, and planetary health is directly rooted in collective traditional knowledge systems globally that prioritize the need for respect and relationships that are collectively actioned through reciprocity. Indigenous traditional knowledge systems themselves are predicated on a deep understanding of Natural or First Law, whose meaning is uniquely rooted within the respective lands globally. 
Irrespective of different geographies, we collectively 'Dream' that in the circle of time, our fellow global citizens will one day recognize Indigenous Natural and First Law while actively acknowledging that our laws have standing and merit. Co-existing with common or crown law in an inclusive way to ensure that all global citizens can live in peace and harmony while ensuring balance and care for our shared "common" home is our only way forward.

Author Contributions: Conceptualization and methodology, N.R., A.P., C.S., D.M.K., C.G., D.P., and B.B.; data curation, writing-original draft preparation, N.R., A.P., C.S., D.M.K., C.G., M.P., and D.P.; review and editing, N.R., A.P., C.S., D.M.K., C.G., M.P., D.P. and B.B. All authors have read and agreed to the published version of the manuscript.

Funding: This research received no external funding.

Acknowledgments: We would like to acknowledge the support and guidance from Elder Damon Polk, an enrolled member of the San Carlos Apache Tribe, in the initial planning of this collaborative work. We also acknowledge the Martuwarra Fitzroy River with Anne Poelina and Marlikka Perdrisat who have extended their hand of friendship, and ask you to visit their River Country and family by connecting to the Martuwarra Fitzroy River Council website: https://www.martuwarrafitzroyriver.org. We acknowledge the fresh water riverene country of Clinton Schultz and his ancestors, and all Gamilaraay Peoples past, present, and future as well as the traditional custodians of the lands upon which he lives, and the custodians of the salt water, the Yugambeh people. We acknowledge the Great Slave Lake, called Tu Nedhe, with the Denésoliné Peoples; Great Bear Lake, called Sahtu, with the Sahtu'ot'ine Peoples; in addition to all of the ancestral homelands of the greater Dene Peoples, including the Dakelhne who are the people who travel by water. We acknowledge the Mau Forest Complex with the Ogiek and Endorois Peoples and all the other Indigenous Peoples and Lands that cross Mother Earth.

Conflicts of Interest: The authors declare no conflict of interest.

\section{References}

1. Cajete, G. Native science: Natural laws of interdependence. In Traditional Ecological Knowledge; Nelson, M.K., Shilling, D., Eds.; Cambridge University Press: Cambridge, UK, 2018; Chapter 2; pp. 15-26.

2. Tauli-Corpuz, V.; United Nations General Assembly. Report of the Special Rapporteur of the Human Rights Council on the Rights of Indigenous Peoples. 29 July 2016. Available online: https://www.un. org/development/desa/indigenouspeoples/wp-content/uploads/sites/19/2019/01/N1624109.pdf (accessed on 25 September 2020).

3. Garnett, S.T.; Burgess, N.D.; Fa, J.E.; Fernández-Llamazares, Á.; Molnár, Z.; Robinson, C.J.; Watson, J.E.M.; Zander, K.K.; Austin, B.; Brondizio, E.S.; et al. A spatial overview of the global importance of Indigenous lands for conservation. Nat. Sustain. 2018, 1, 369-374. [CrossRef]

4. Crook, M.; Short, D.; South, N. Ecocide, genocide, capitalism and colonialism: Consequences for Indigenous peoples and global ecosystems environments. Theor. Criminol. 2018, 22, 298-317. [CrossRef]

5. McDaniel, M. Professor Michael McDaniel Speaks at the Launch of Allens' Reconciliation Action Plan. 10 May 2012. Available online: https:/www.youtube.com/watch?v=Y8LP4GSk0Y0 (accessed on 25 September 2020).

6. 'yotti' Kingsley, J.; Townsend, N.; Phillips, R.; Aldous, D. "If the Land is Healthy ... It Makes the People Healthy": The relationship between caring for country and health for the Yorta Yorta Nation, Boonwurrung and Bangerang tribes. Health Place 2009, 15, 291-299. [CrossRef] [PubMed]

7. Schultz, C. Factors of Holistic Wellbeing for Members of the Aboriginal Health and Community Workforce. Ph.D. Thesis, Griffith University, Brisbane, Australia, 2020.

8. Redvers, N.; Schultz, C.; Prince, M.V.; Cunningham, M.; Jones, R.; Blondin, B. Indigenous perspectives on education for sustainable healthcare. Med. Teach. 2020. [CrossRef] [PubMed]

9. RiverOfLife, M.; Poelina, A.; Bagnall, D.; Lim, M. Recognizing the Martuwarra's First Law Right to Life as a living ancestral being. Transnatl. Environ. Law 2020. [CrossRef]

10. O'Donnell, E.; Poelina, A.; Pelizzon, A.; Clark, C. Stop Burying the Lede: The Essential Role of Indigenous Law(s) in Creating Rights of Nature. Transnatl. Environ. Law 2020, 1-25. [CrossRef]

11. Rose, D.B. Common Property Regimes in Aboriginal Australia: Totemism Revisited. In The Governance of Common Property in the Pacific Region; Larmour, P., Ed.; ANU Press: Canberra, Australia, 2013; Chapter 9; pp. 127-143. Available online: http://press-files.anu.edu.au/downloads/press/p229161/pdf/ch092.pdf (accessed on 25 September 2020). 
12. Federal Court of Australia. Fortescue Metals Group v Warrie on Behalf of the Yinjibarndi People [2019]; FCAFC 177. Available online: https://www.judgments.fedcourt.gov.au/_data/assets/word_doc/0003/536277/ 2017FCA1299.docx?v=0.1.2 (accessed on 18 October 2019).

13. Couchere, D. Indigenous Values on Climate Change. Cultural Survival, 23 September 2019. Available online: https://www.culturalsurvival.org/news/indigenous-values-climate-change (accessed on 25 September 2020).

14. Rockström, J.; Steffen, W.; Noone, K.; Persson, Å.; Chapin, F.S., III; Lambin, E.; Lenton, T.M.; Scheffer, M.; Folke, C.; Schellnhuber, H.; et al. Planetary Boundaries: Exploring the Safe Operating Space for Humanity. Ecol. Soc. 2009, 14, 32. Available online: https://www.ecologyandsociety.org/vol14/iss2/art32/ (accessed on 25 September 2020).

15. Bennett, T.C.B.; Maynard, N.; Cochran, P.; Gough, R.; Lynn, K.; Maldonado, J.; Voggesser, G.; Wotkyns, S.; Cozzetto, K. Indigenous Peoples, Lands, and Resources. Climate Change Impacts in the United States: The Third National Climate Assessment. In Climate Change Impacts in the United States: The Third National Climate Assessment; Melillo, J.M., Richmond, T.C., Yohe, G.W., Eds.; USA Global Research Program: Washington, DC, USA, 2014; Chapter 12; pp. 297-317. Available online: https://www.climatehubs.usda.gov/sites/default/files/ NCA3_Full_Report_12_Indigenous_Peoples_LowRes.pdf (accessed on 25 September 2020).

16. Jones, R. Climate change and Indigenous health promotion. Glob. Health Promot. 2019, 26, 73-81. [CrossRef]

17. IPBES; Brondizio, E.S.; Settele, J.; Díaz, S.; Ngo, H.T. (Eds.) Global Assessment Report on Biodiversity and Ecosystem Services of the Intergovernmental Science-Policy Platform on Biodiversity and Ecosystem Services, 2019; IPBES Secretariat: Bonn, Germany, 2019.

18. United Nations. Convention on Biological Diversity. 1992. Available online: https://www.cbd.int/doc/legal/ cbd-en.pdf (accessed on 25 September 2020).

19. United Nations. Convention on Biological Diversity. In Nagoya Protocol on Access and Benefit-sharing and Traditional Knowledge; United Nations: New York, NY, USA, 2011.

20. Redvers, N.; Yellow Bird, M.; Quinn, D.; Yunkaporta, T.; Arabena, K. Molecular decolonization: An Indigenous microcosm perspective of planetary health. Int. J. Environ. Res. Public Health 2020, 17, 4586. [CrossRef] [PubMed]

21. Ogiek Bio-Cultural Community Protocol (BCP). Safeguarding Rights and Managing Resources to Improve Livelihoods, 2nd ed.; Ogiek Peoples' Development Program: Egerton, Kenya, 2015; Available online: https://www.ogiekpeoples. org/images/downloads/Ogiek-Bio-Cultural-Protocol.pdf (accessed on 25 September 2020).

22. Endorois Welfare Council (EWC). Endorois Peoples' Biocultural Protocol: Sustainable Biodiversity Resource Management for Access and Benefit Sharing and Protection from Threats to Culture. 2019. Available online: http://www.abs-initiative.info/fileadmin//media/Knowledge_Center/Pulications/BCPs/ Endorois-Peoples-Biocultural-Protocol.pdf (accessed on 25 September 2020).

23. Kobei, D. Significance of the MAU. In Ogiek Peoples' Development Program (OPDP) (Internal Document); Ogiek Peoples' Development Program: Egerton, Kenya, 2020.

24. Ashamu, E. Centre for Minority Rights Development (Kenya) and Minority Rights Group International on behalf of Endorois Welfare Council v Kenya: A landmark decision from the African Commission. J. Afr. Law 2011, 55, 300-313. [CrossRef]

25. African Court on Human and Peoples' Rights. African Commission on Human and People's Rights v. Republic of Kenya, Judgment 26 May 2017. Available online: https:/en.african-court.org/images/Cases/Judgment/ Application\%20006-2012\%20-\%20African\%20Commission\%20on\%20Human\%20and\%20Peoples\%E2\%80\% 99\%20Rights\%20v.\%20the\%20Republic\%20of\%20Kenya.pdf (accessed on 24 September 2020).

26. Claridge, L. Litigation as a tool for community empowerment: The case of Kenya's Ogiek. Erasmus Law Rev. 2018, 11. [CrossRef]

27. Poelina, A.; Webb, T.; Smith, A.S.; Smith, N.; Wright, S.; Hodge, P.; Daley, L.; Woodward, E.; Yates, P.; Hill, R. Foundations of Our Knowledge Our Way. In Our Knowledge Our Way in Caring for Country: Indigenous-led Approaches to Strengthening and Sharing Our Knowledge for Land and Sea Management; Woodward, E., Hill, R., Harkness, P., Archer, R., Eds.; CSIRO and HAILSMA: Canberra, Australia, 2020; Chapter 1; pp. 1-20. Available online: https://www.nespnorthern.edu.au/wp-content/uploads/2020/07/Our-Knowledge-Our-WayGuidelines.pdf (accessed on 25 September 2020).

28. SDG Knowledge Hub. IPBES Global Assessment Finds We Must Act Now to Save Our Life Support System. Available online: https://sdg.iisd.org/news/ipbes-global-assessment-finds-we-must-act-now-to-save-ourlife-support-system (accessed on 25 September 2020). 
29. Mamo, D. (Ed.) The Indigenous World 2020, 34th ed.; The International Work Group for Indigenous Affairs (IWGIA): Copenhagen, Denmark; Available online: http://iwgia.org/images/yearbook/2020/IWGIA_The_ Indigenous_World_2020.pdf (accessed on 25 September 2020).

30. Redvers, N. The Science of the Sacred: Bridging Global Indigenous Medicine Systems and Modern Scientific Principles; North Atlantic Books: Berkeley, CA, USA, 2019.

31. Northern Ice. Dene Environmental Laws (n.d.) (Internal Document); Northern Integrated Culture with the Environment: Yellowknife, NWT, Canada, 2014.

32. Voices of Amiskwaciy. Wahkohtowin: Cree Natural Law (n.d.). Edmonton Public Library. Available online: https://voicesofamiskwaciy.ca/digital-heritage/wahkohtowin-cree-natural-law (accessed on 25 September 2020).

33. The Gifts of the Seven Grandfathers (n.d.). Available online: https://ojibwe.net/projects/prayers-teachings/ the-gifts-of-the-seven-grandfathers/ (accessed on 25 September 2020).

34. Seven Generations International Foundation. 7th Generation Principle. Available online: http://7genfoundation. org/7th-generation/ (accessed on 17 October 2020).

35. Black, C.F. The Land Is the Source of the Law: A Dialogic Encounter with Indigenous Jurisprudence; Routledge-Cavendish: New York, NY, USA, 2010.

36. Spearim, P.; Gamilaraay Peoples, Australia. Personal Communication, 2020.

37. Waters, M. Nurturing the "Beginning" in protecting our traditional practices from the end: Family, kinship and Kamilaroi Aboriginal First Nation Knowledge in Australia. J. Eur. Assoc. Stud. Aust. 2013, 4, 177-192.

38. McDermott, R.; O’Dea, K.; Rowley, K.; Knight, S.; Burgess, P. Beneficial impact of the Homelands Movement on health outcomes in Central Australian Aborigines. Aust. N. Z. J. Public Health 2008, 22. [CrossRef]

39. Burgess, C.P.; Johnston, F.H.; Berry, H.L.; McDonnell, J.; Yibarbuk, D.; Gunabarra, C.; Mileran, A.; Bailie, R.S. Healthy country, healthy people: The relationship between Indigenous health status and "Caring for Country". Med. J. Aust. 2009, 190, 567-572. [CrossRef]

40. Australian Government. Royal Commission into National Natural Disaster Arrangements: Interim Observations. Office of the Royal Commission, Ed.; Available online: https:/naturaldisaster.royalcommission.gov.au/system/ files/2020-08/Interim\%20Observations\%20-31\%20August\%202020_0.pdf (accessed on 29 September 2020).

41. WWF-Australia. Australia's 2019-2020 Bushfires: The Wildlife Toll. Available online: https://www.wwf.org.au/ what-we-do/bushfire-recovery/in-depth/resources/australia-s-2019-2020-bushfires-the-wildlife-toll\#gs.iexvyjv (accessed on 17 October 2020).

42. Verbos, A.K.; Humphries, M. A Native American Relational Ethic: An Indigenous Perspective on Teaching Human Responsibility. J. Bus. Ethics 2013, 123, 1-9. [CrossRef]

43. Toledo, V.M. Indigenous Peoples and Biodiversity. Geography 2013, 269-278. [CrossRef]

44. Tollefson, J. Why deforestation and extinctions make pandemics more likely. Nature 2020, 584, $175-176$. Available online: https://www.nature.com/articles/d41586-020-02341-1\#: \{\}:text=As\%20humans\%20diminish\% 20biodiversity\%20by,pandemics\%20such\%20as\%20COVID\%2D19 (accessed on 17 October 2020). [PubMed]

45. United Nations. United Nations Declaration on the Rights of Indigenous Peoples. Available online: https://www. un.org/development/desa/indigenouspeoples/declaration-on-the-rights-of-indigenous-peoples.html (accessed on 19 October 2020).

46. United Nations. Free Prior and Informed Consent: An Indigenous Peoples' Right and a Good Practice for Local Communities: FAO. 14 October 2016. Available online: https://www.un.org/development/desa/ indigenouspeoples/publications/2016/10/free-prior-and-informed-consent-an-indigenous-peoples-right-anda-good-practice-for-local-communities-fao/ (accessed on 19 October 2020).

47. Redvers, N. The Value of Global Indigenous Knowledge in Planetary Health. Challenges 2018, 9, 30. [CrossRef]

Publisher's Note: MDPI stays neutral with regard to jurisdictional claims in published maps and institutional affiliations. 